\title{
A Literature Review on Cold-Formed Steel-Timber Composite Structures
}

\author{
Fabiana Y. Moritani, ${ }^{\mathrm{a}, *}$ Carlos E. J. Martins, ${ }^{\mathrm{a}, \mathrm{b}}$ and Alfredo M. P. G. Dias ${ }^{\mathrm{b}}$ \\ State-of-the-art steel-timber composite structures (STC), using cold- \\ formed steel (CFS) and cross-laminated timber (CLT), are considered in \\ this review. Literature on this type of construction solution is reviewed to \\ provide an overview of the characteristics and advantages of STC. \\ Previous experimental and numerical studies with STC structures, mainly \\ composite solutions with CFS beams and CLT panels, are discussed to \\ assess the behavior of this structural typology. A comprehensive \\ description of the connection systems performance in different STC \\ structures is also provided. Furthermore, the design and analytical \\ methods currently available are presented. Likewise, details on aspects \\ related to dynamic properties and fire resistance are discussed.
}

Keywords: Cold-formed steel; Cross-laminated timber; Composite structures; Connection; Hybrid structures; Wood-based structures

Contact information: a: SerQ-Centro de Inovação e Competências da Floresta, Rua J, $N^{\circ}$ 9, Zona Industrial da Sertã, 6100-711 Sertã, Portugal; b: ISISE - Institute for Sustainability and Innovation in Structural Engineering, Departamento de Engenharia Civil, Faculdade de Ciências e Tecnologia, Universidade de Coimbra, Rua Luís Reis Santos, Pólo II da FCTUC, 3030-788 Coimbra, Portugal;

*Corresponding author: fabianamoritani@gmail.com

\section{INTRODUCTION}

Composite structures combine the benefits of different materials to overcome their limitations and increase their performance (Ceccotti 2002; Dias 2012; Wacker et al. 2020). Steel-timber composite (STC) for buildings presents many advantages that have proved to be effective as a structural solution, for instance, higher strength to weight ratio, lower environmental impact, and the possibility of recycling and replacing degraded elements (Hassanieh et al. 2017a; Loss et al. 2016a). Composite solutions that consider steel profiles and cross-laminated timber (CLT) panels enable highly industrialized construction; as such, combinations allow a quick connection of the elements with higher precision, using a full-dry system. The STC structures do not require concrete molding or completion on site of precast concrete elements, as is usually required by other composite solutions such as timber-concrete (Loss et al. 2016a). It is also worth noting that structural components may be reversible during the service life of the construction, since STC system designed with fasteners such as screws and bolts allows the deconstruction and potential reuse and/or recycling of construction materials (Hassanieh et al. 2016b; Loss et al. 2016a). If a wooden design is adopted, it results in lower environmental impacts and embodied energy because timber is known as a carbon sink, lowering the carbon footprint of such structures (Asdrubali et al. 2017; Bradford et al. 2017).

The technical possibilities for building with timber have experienced a big advance in recent years. Efforts in developments involving timber and composite are being motivated by environmental concerns. The STC solutions can be considered as a new 
generation of structural technologies for which the construction system is implemented using modular STC highly-prefabricated elements, and it has considerable potential for construction industry and commercialization (Loss et al. 2016a,b). According to Loss et al. (2016a) three important examples of buildings of timber hybrid tall buildings can be found in Europe that emphasize the wide possibilities for lightweight modern buildings and sustainable solutions; these include structures built in Norway - Treet (Bjertnæs and Malo, 2014); in Austria - Lifecycle Tower (Rhomberg and Bonomo 2011); and in London - Banyan Wharf.

Combinations of timber with steel can also be made in other ways, for instance, timber panels and steel beams (Kyvelou et al. 2015; Loss et al. 2016b; Hassanieh et al. 2017a; Loss and Davison 2017); timber-concrete composite slabs with steel profile (Kuhlmann and Schänzlin 2008); steel frame with timber wall panels (Loss et al. 2016a); and timber slabs with steel beams and column (Xu et al. 2014; Keipour et al. 2018b; Nouri and Valipour 2019; Keipour et al. 2018a; Ataei et al. 2019b; Nouri et al. 2019). At the structural element level, steel sheets can be used to reinforce timber beams (Hassanieh et al. 2016b; Ataei et al. 2019b), and beam-beam connections can be completed using steel sheets and screws, or through steel beams as the mainframe in an STC floor.

The CFS structural elements provide lightness, flexibility, and extra potential for bringing material recycling to the composite solution. On the other hand, such characteristics tend to increase the potential for instability issues of the CFS profile. This problem can be reduced through bracing, which can be provided by the timber member (e.g., particle boards, plywood panels, laminated veneer lumber, or cross-laminated timber), through an appropriate detailing. In recent years, the use of CFS beams supporting timber panels has gained market share as a flooring system in industrial and commercial buildings (Vella et al. 2020). This composite solution requires an efficient connection system to guarantee the composite action, allowing a more efficient use of the materials, and decreasing the execution time. According to Loss and Davison (2017), the association of the CFS beams and CLT can also satisfy requirements in terms of prefabrication, modularity, sustainability, on-site installation, and relative manufacturing costs.

This paper aims to provide a review of previous research studies on STC structural solutions, specifically the development of composite structures with CFS and CLT. Studies on properties of STC, connection systems, design and analytical methods of composite structures, short- and long-term behavior, and numerical analysis are presented and discussed.

\section{RELATED WORKS ON STEEL-TIMBER COMPOSITE (STC)}

Loss et al. (2014, 2016a,b) developed an extended study concerning the construction system with prefabricated steel-timber components in highly industrialized modular construction, combining CLT panels with different steel profiles (hot-rolled steel, cold-formed steel, and welded steel). Connection solutions were investigated to reduce time consumption and costs of construction.

According to Loss et al. (2016b) the impact in the building market and the structural efficiency of the STC structures is remarkable when compared to other composite systems such as timber-concrete or steel-concrete. 
Figure 1 shows three composite structural solutions designed considering similar capacity, in free span $(6 \mathrm{~m})$, height of the cross-section $(252 \mathrm{~mm})$, design loads, and deflection in the serviceability limit state (1/250). Structural performances were estimated without the composite action $(k=0)$ and with full-composite action $(k=\infty)$. From the comparison of composite slabs with steel-concrete, timber-concrete and steel-timber, it can be seen that the STC system with CLT panels and steel profiles is equivalent to the other systems, in terms of the bending stiffness and design load carrying capacity. The selfweight of STC slab was found to be four times lower than steel-concrete slab. The capacityto-self-weight ratio of STC section was $17.02(k=0)$ and $36.21(k=\infty)$, while the capacityto-self-weight ratio of steel-concrete section was $3.02(k=0)$ and $8.40(k=\infty)$ and for timber-concrete was $5.40(k=0)$ and $18.80(k=\infty)$. In general, steel-timber systems offer advantages of each material creating very slim and light floor components and, therefore, leading to lightweight constructions, which provides cutting-down the forces acting on the foundations and reducing the seismic effects on the structure.

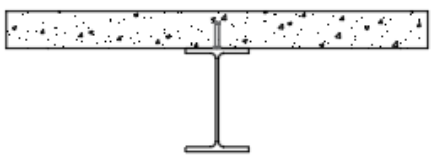

Steel-concrete composite

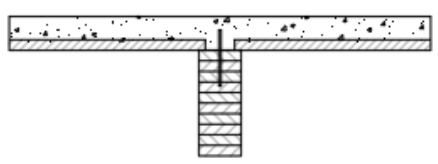

Timber-concrete composite

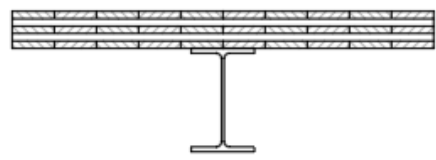

Steel-timber composite

Fig. 1. Composite slab systems (Adapted from Loss et al. 2016b)

Loss and Davison (2017) performed an experimental campaign and numerical modeling to access the flexural behavior of a floor system composed of prefabricated ultralight modular components. The proposed solution was implemented to support the design loads and serviceability conditions for the main floor of a residential building comprised of CLT panel and two custom-made CFS beams joined with mechanical connectors and an epoxy-based resin (Fig. 2).

The ultimate loads were not reached and, therefore, the load carrying capacity $\left(F_{\mathrm{c}}\right)$ was assumed to a deflection limit in terms of accepted damage and potential local breakages in the steel beams (up to the deflection of $1 / 40$ and 1/60). The tested systems showed a considerable structural efficiency with effective stiffness close to 0.76 and high capacity-to-weight ratio $\eta_{F}\left(\eta_{F}=F_{\mathrm{c}} / W_{\mathrm{p}}\right.$, where $F_{\mathrm{c}}$ is the load carrying capacity and $W_{\mathrm{p}}$ is the self-weight of specimens) up to 80.6, while the capacity-to-weight ratio of STC by Loss et al. (2016b) was 36.21 with full-composite action. The STC solutions help to overcome the limits of the timber elements in terms of serviceability under service loads. While the CFS beams achieved inelastic deformations at high loading levels (four of five times higher than the design loads) and connections undergo ductile behavior, the CLT remained at an elastic level and substantially intact after the tests. In the specimens, pulled-out screws were detected, as well as local buckling in the flanges of the mid-span section, and deformation at the restraints. Besides, these floor systems remained in equilibrium, since the instability CFS beams was prevented by the connection with CLT, which provides a very high ductility even for large flexural deformation. Two types of restraints were compared. It was shown that the adoption of fixed restraints at the ends of the CFS beams could increase the stiffness by $40 \%$ and the strength of the floors by $37 \%$. According to Kyvelou et al. (2018), such results were previously achieved by $\mathrm{Xu}$ and Tangorra (2007) and Lawson et al. (2006). 

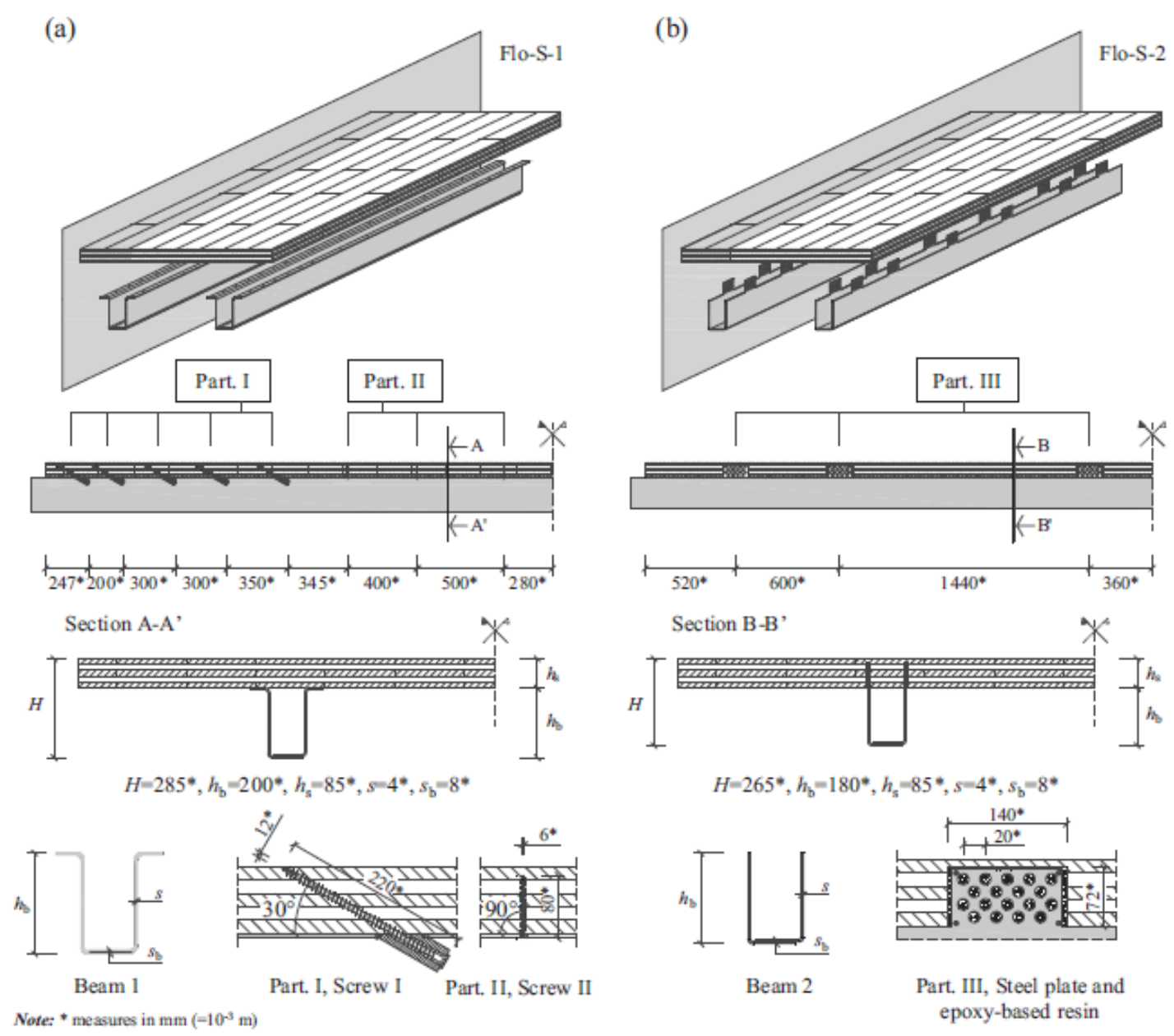

Fig. 2. Two types of prefabricated floor developed with CFS and CLT components (republished from Loss and Davison (2017) with permission from Elsevier)

Hassanieh (2017) developed research on the short- and long-term behavior of STC structures for large-scale construction, with CLT and LVL (laminated veneer lumber) panels connected to steel beams by mechanical fasteners and adhesives. Different types of bonding systems in STC structures were evaluated, and improved solutions were proposed. The load-slip behavior, load carrying capacity, and failure modes were evaluated for the steel-CLT composite joints of three different types of connections (i.e. high-strength bolts, coach screws, and combination of glued with coach screws). The influence of reinforcement by using steel nail plates was verified by Hassanieh et al. (2016c), through push-out tests. In Fig. 3 the failure modes in steel-CLT connections are presented, namely the crushing zone and densification of grains (Fig. 3ac-c) and the failure Mode II with plastic hinge in coach screws (Fig. 3d-f). The reinforcement of the CLT panels using nail plates increased the initial stiffness and strength, but it had no influence on the failure mode of the screw connection, since a slight decrease in the ductility was observed. In general, screwed connections presented ductile behavior, whereas the combination of adhesives and screws had higher load carrying capacity and stiffness compared with the conventional connections. In the opposite way, this connection presented an undesirable brittle failure associated with the failure of the adhesive and the splitting of the CLT panel from the steel 
beam (Hassanieh et al. 2016c). The performance of a composite floor comprising steel beams and CLT panels connected by a high-strength bolted shear connection embedded in a grout pocket (BGP) and conventional shear connectors (coach screw, dog screw e bolts) was assessed by Hassanieh et al. (2017a). Connections with BGP showed higher initial stiffness, pre-peak stiffness, and peak load capacities compared to conventional connectors (i.e. coach screw and dog screw); however, the width of the grouted pockets had little or no influence on the pre-peak load-slip behavior of the joints.

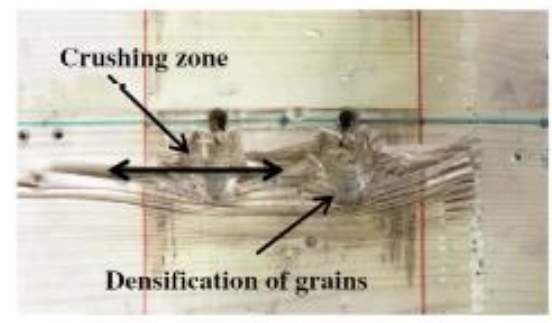

(a)

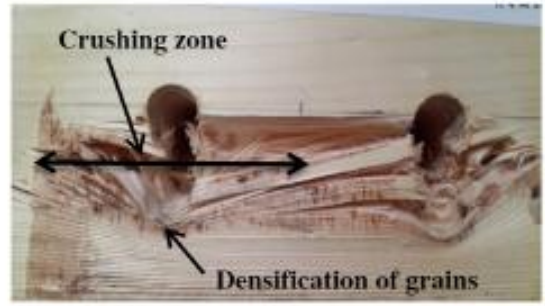

(b)

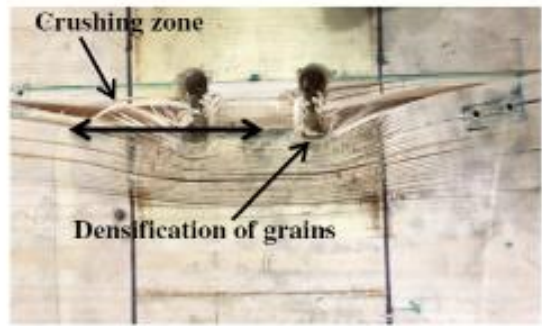

(c)

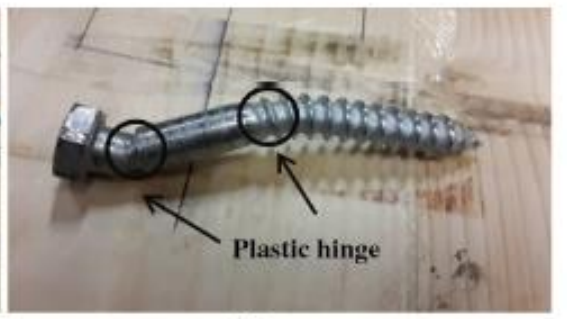

(d)

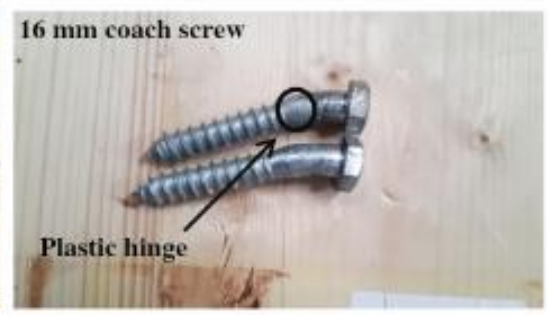

(e)

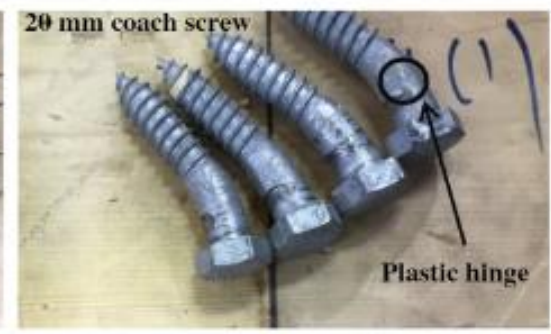

(f)

Fig. 3. Failure modes in steel-CLT with screw connectors (a-c) Crushing zone and densification of grains, (d-f) Plastic hinge of the coach screws (republished from Hassanieh et al. (2017a) with permission from Elsevier)

Chiniforush et al. (2019b) assessed the long-term behavior of STC connections using four different types of connectors (i.e. coach screws, dog screws, post-tensioned high strength bolts, and high strength bolts embedded in grout pocket). A proposed rheological model was used to predict the slip and thus to calculate the creep coefficient of the STC structure over a service life of 50 years. The model was calibrated from the experimental results that considered the effect of the stiffness change due to the variation of the moisture content, temperature, creep, mechanic-sorption, and inelastic shrinkage. The results showed that an increase in the load level of $30 \%$ of the ultimate load capacity led to up to $70 \%$ reduction in the slip modulus of the coach screws, dog screws, and post-tensioned bolts connectors. However, the reduction in the bolts in grout pockets connectors was limited to $40 \%$.

An extensive experimental and numerical study on shear interaction of the hybrid system comprising a CFS beam and wood-based panel was carried out by Kyvelou et al. 
(2015) and then Kyvelou et al. (2017b). The spacing of the fasteners and the application of adhesives at the interface between the CFS beam and floorboards had a significant effect on the bending moment capacity of the flooring system. The best performance achieved up to $68 \%$ of composite action, which turned into a $100 \%$ increase in the bending moment capacity and a $42 \%$ increase in effective stiffness.

The CFS elements had some drawbacks, namely those regarding compressive stresses, which governs the buckling behavior of the elements. Awaludin et al. (2015) assessed the mechanical performance of a CFS member stiffened by timber lamellae. CFS profiles of double Z-, C- and double C-sections and $14 \mathrm{~mm}$ thick planks of the Swietenia mahagoni species were considered, with $12 \%$ moisture content and a specific gravity of 0.69. The load-carrying capacity and the buckling failure mode of the cold-formed steel structure and the CFS-timber composite structure were determined and compared. The composite section showed an increase in the buckling load capacity comparing with the non-composite section. However, at the critical load, the gain varied from 1.4 for longer spans to 6.7 for shorter spans.

The performance of a roof made of structural truss elements with a span of $25 \mathrm{~m}$ composed of CFS profiles reinforced with timber lamellas was assessed by Irawati et al. (2017). The analysis of the compressive capacity of CFS-laminated timber was conducted using a full composite action assumption. The CFS-timber composite structures obtained satisfactory results, as they supported the maximum external load. Besides, the deflection of the composite structure $(1.74 \mathrm{~cm})$ was lower than the maximum allowable deflection $(12.50 \mathrm{~cm})$. CFS profiles achieved the critical buckling load until the external load, so unreinforced CFS profiles as the main compressive elements may not be recommended.

Chiniforush et al. (2018) studied the life-cycle energy of a floors and shear walls system adopting STC elements by accounting for energy use in material extraction and processing. The results indicated a decrease in the embodied energy at the expense of only a slight increase in the operating energy. Furthermore, a considerable life cycle energy saving was found in STC floors adoption when compared with the same building designed with a concrete structure.

Izumi et al. (2016) developed a non-loaded combustion test and numerical modeling of the different types of cross-sections comprising the association CFS and glulam in the beam element. According to the authors, this association increased the structural and fire performance of the composite beam. Akotuah et al. (2015) studied the effect of shear connection geometry of a hybrid steel-timber under fire by full-scale tests. The results showed that the fire resistance of the connection depends on the load ratio, the connection type, and the relative exposure of the steel-timber section. Due to the high conductivity of the steel, the wood charred at the connection regions, and this effect initiated brittle failure and propagation of the crack, which led to the ultimate failure of the assembly. The CFS profiles at high temperatures have their load-carrying capacity affected due to the reduction of the yield strength and the modulus of elasticity, as well as the appearance of additional stresses by expansion restriction and secondary stresses due to deformations caused by the temperature gradient.

According to the facts previously presented, the STC structures combine the performance of each material (steel and timber) to overcome their drawbacks. The CFS elements are susceptible to buckling effects; however, the modulus of elasticity is significantly higher than the modulus of elasticity of the CLT. Life cycle assessments and energy of wooden composite systems shows lower environmental impacts and higher savings in embodied energy and carbon. The experimental studies of composite structures 
comprised of CFS and CLT showed considerable structural efficiency, reflected in the effective stiffness and enhancement of the load-carrying capacity, but the behavior was strongly dependent on the performance of the components of the connection system. The studies on the behavior and enhancement of each connection system tested are explained in the next section. Since the CFS profiles under high temperatures presents a decrease in their mechanical properties, the CFS-CLT composite solution should be also investigated in order to guarantee the performance under fire, mainly in the CFS elements. Table 1 provides a summary of the advantages and disadvantages of each STC system (CFS-CLT, steel-CLT, steel-LVL, and CFS-wood based panel).

Table 1. Advantages and Disadvantages of each STC System

\begin{tabular}{|c|c|c|c|}
\hline $\begin{array}{l}\text { STC } \\
\text { system }\end{array}$ & Advantages & Disadvantages & Reference \\
\hline CFS-CLT & $\begin{array}{ll}\text { - } & \text { Modular prefabricated } \\
\text { - } & \text { Qunstruction; } \\
\text { - } & \text { Dry construction; } \\
\text { - } & \text { Lower environmental impact; } \\
\text { - } & \text { High capacity-to-weight ratio; } \\
\text { - } & \text { Renewable and reusable } \\
\text { materials; } \\
\text { - } \quad \text { Lightweight solution; } \\
\text { - } & \text { Diaphragm behavior } \\
\text { produced by CLT panels; } & \text { CFS provides lightness; } \\
\text { flexibility in different cross- } \\
\text { sectional shapes; easy } \\
\text { transportation; cost effective. }\end{array}$ & $\begin{array}{l}\text { - } \quad \text { Susceptible to local } \\
\text { buckling and deformation } \\
\text { at the restraints; } \\
\text { Requires skilled labor and } \\
\text { can be more expensive } \\
\text { due to the assembly and } \\
\text { manufacturing cost. }\end{array}$ & $\begin{array}{l}\text { Loss and } \\
\text { Davison } \\
\text { (2017) } \\
\text { Navaratnam } \\
\text { et al. (2021) }\end{array}$ \\
\hline $\begin{array}{l}\text { Steel-CLT } \\
\text { Steel-LVL }\end{array}$ & $\begin{array}{ll}\text { - } & \text { Modular prefabricated } \\
\text { - } & \text { Qonstruction; } \\
\text { - } & \text { Drickly assembly method; } \\
\text { - } & \text { Lower environmental impact; } \\
\text { - } & \text { Higher bending stiffness and } \\
\text { capacity-to-weight ratio; } \\
\text { - } \quad \text { Slim light floors; } \\
\text { - } & \text { Structural stability } \\
& \text { (interaction between } \\
\text { diaphragms and shear wall); } & \text { Improved durability and fire } \\
\text { - } & \text { resistance. }\end{array}$ & $\begin{array}{l}\text { - Composite connection } \\
\text { design is the main } \\
\text { challenge; } \\
\text { Requires skilled labor and } \\
\text { can be more expensive } \\
\text { than conventional } \\
\text { construction system due to } \\
\text { the manufacturing, } \\
\text { transportation, and } \\
\text { integration cost. }\end{array}$ & $\begin{array}{l}\text { Loss et al. } \\
\text { (2016a,b) } \\
\text { Loss and } \\
\text { Frangi } \\
\text { (2017) } \\
\text { Hassanieh et } \\
\text { al. (2016b) } \\
\text { Hassanieh et } \\
\text { al. (2017a) }\end{array}$ \\
\hline $\begin{array}{l}\text { CFS-Wood } \\
\text { based } \\
\text { products } \\
\text { (particle } \\
\text { board, } \\
\text { plywood, } \\
\text { OSB) }\end{array}$ & $\begin{array}{ll}\text { - } & \text { Lightness, efficient, and } \\
\text { economical solution; } \\
\text { - } \quad \text { Lower environmental impact; } \\
\text { - } \quad \text { Presents a significant } \\
\text { improvement in terms of } \\
\text { structural performance and } \\
\text { load carrying capacity. }\end{array}$ & $\begin{array}{ll}\text { - } & \text { Presents lower stiffness } \\
\text { and load carrying capacity } \\
\text { compared with other } \\
\text { composite systems; } \\
\text { - Poor durability, mainly, } \\
\text { without treated } \\
\text { preservative; } \\
\text { Susceptible to local and } \\
\text { distortional buckling. }\end{array}$ & $\begin{array}{l}\text { Kyvelou et } \\
\text { al. }(2017 a, b) \\
\text { Lawson et } \\
\text { al. (2006) } \\
\text { Lawson et } \\
\text { al. (2008) } \\
\text { Sani et al. } \\
(2019)\end{array}$ \\
\hline
\end{tabular}




\section{CONNECTION SYSTEMS}

Studies have been carried out to obtain a more efficient and low-cost connection system. The following tables summarize the results of steel-timber connection types present in the literature, namely the average values of ultimate load capacity $\left(F_{\mathrm{u}}\right)$ and the service connection stiffness $\left(k_{\mathrm{s}}\right)$. It is worth mentioning that for each material composition and design of the connection system, results were obtained inherent to each study, generating a great variability of results for the same properties of load carrying capacity and stiffness.

Awaludin et al. (2016) evaluated the connection of CFS and timber lamellas using two bolts and two different side plates (plywood and steel). The connection system using steel side plates was able to accommodate the strength increase of a composite member, as this connection system had an ultimate load-carrying capacity four times higher and initial joint slip modulus $36 \%$ higher than the CFS connections without plates. The composite connection with plywood plates did not provide a significant increase compared to the CFS connections without plates.

According to Vella et al. (2020), the inclined screws decrease the risk of the two composite members separating under shear stress due to the component of force within the connector that acts perpendicular to the shear plane. The authors carried out an experimental study on connections between CFS and wood-based panels (particleboard and plywood) formed with inclined screws. The screwed connections were considered with or without wings, inclined $0^{\circ}$ and $45^{\circ}$ from a normal to the steel-timber interface that were installed parallel to each other. Table 2 showed that the non-winged screws inclined at $45^{\circ}$ had a higher load-carrying capacity and initial slip modulus for both plywood and particleboard. The enhancement of the peak load-carrying compared to the reference specimen was about $30 \%$, while the enhancement of the slip modulus was up to $140 \%$. There was no significant effect of the steel thickness on the connection stiffness or peak load capacity unless the failure was governed by thread withdrawal.

Loss et al. (2016a) tested different connection solutions for steel-timber hybrid prefabricated systems. Specific connections for the composite section and other types used to fasten the CLT panels all together and to connect these to the main steel frame were tested. The authors recommended that the I-A-1 and I-A-3 connectors should be used to join CLT panels with the steel frames and I-B-7 connectors were used to build steel-timber composite systems such as prefabricated floor elements. These connections allowed a quick joining of components on-site and provided an enhanced inelastic deformation capacity. The experimental results are listed in Table 3. According to Loss et al. (2016a), the I-B-7 was the best solution to build STC floor elements that ensured a higher loadbearing capacity and high slip modulus $(372.4 \mathrm{kN} / \mathrm{mm})$, as well as improved ductility capacity.

Hassanieh et al. (2016c) reported that the use of nail plates to reinforce the CLT slightly reduced the ductility of screws but did not modify the failure mode of the joints with screw connectors. The effect of the grout pocket in bolted connections was evident, showing a slip modulus five times higher compared with the same connector without grout pocket. The load-slip responses of screw connectors exhibited close to elastic-perfectly plastic and relatively ductile behavior, while the load-slip responses of bolted connectors showed some hardening characteristics and brittle failure mode. In the glued steel-CLT composite joints, a non-sag gel type epoxy resin was used with $16 \mathrm{~mm}$ coach screw to 
provide full composite action that exhibited significantly higher strength and stiffness compared to the joints with only mechanical connectors.

Table 2. Mean Values of the Mechanical Properties of Connections Systems with CFS and Timber

\begin{tabular}{|c|c|c|c|}
\hline Connection system & $\begin{array}{c}F_{\mathrm{u}} \\
(\mathbf{k N})\end{array}$ & $\begin{array}{c}k_{\mathrm{s} 0.4} \\
(\mathrm{kN} / \mathrm{mm})\end{array}$ & $\begin{array}{c}\text { Reference } \\
\text { composite } \\
\text { solution }\end{array}$ \\
\hline Connection of the CFS members without plates; & 12.1 & 5.45 & \multirow{3}{*}{$\begin{array}{c}\text { Awaludin et al. } \\
(2016) \\
\text { CFS-Timber }\end{array}$} \\
\hline Connection of composite member with steel plates; & 55.5 & 7.43 & \\
\hline Connection of composite member with plywood plates; & 17.6 & 4.46 & \\
\hline $\begin{array}{l}\text { Particleboard with CFS of the } 1.5 \mathrm{~mm} \text { thick; winged } \\
\text { screws; screws angle: } 0^{\circ} \text {; }\end{array}$ & 5.58 & 0.98 & \multirow{12}{*}{$\begin{array}{c}\text { Vella et al. } \\
(2020) \\
\text { CFS-Wood } \\
\text { based panel }\end{array}$} \\
\hline $\begin{array}{l}\text { Particleboard with CFS of the } 1.5 \mathrm{~mm} \text { thick; winged } \\
\text { screws; screws angle: } 45^{\circ}\end{array}$ & 5.70 & 1.35 & \\
\hline $\begin{array}{l}\text { Particleboard with CFS of the } 1.5 \mathrm{~mm} \text { thick; non- } \\
\text { winged screws, screws angle: } 45^{\circ}\end{array}$ & 6.63 & 1.38 & \\
\hline $\begin{array}{l}\text { Particleboard with CFS of the } 2.4 \mathrm{~mm} \text { thick, winged } \\
\text { screws, screws angle: } 0^{\circ}\end{array}$ & 7.06 & 1.24 & \\
\hline $\begin{array}{l}\text { Particleboard with CFS of the } 2.4 \mathrm{~mm} \text { thick; winged } \\
\text { screws, screws angle: } 45^{\circ}\end{array}$ & 6.37 & 1.37 & \\
\hline $\begin{array}{l}\text { Particleboard with CFS of the } 2.4 \mathrm{~mm} \text { thick; non- } \\
\text { winged screws, screws angle: } 45^{\circ}\end{array}$ & 7.50 & 1.86 & \\
\hline $\begin{array}{l}\text { Plywood with CFS of the } 1.5 \mathrm{~mm} \text { thick; winged screws; } \\
\text { screws angle: } 0^{\circ}\end{array}$ & 4.88 & 0.55 & \\
\hline $\begin{array}{l}\text { Plywood with CFS of the } 1.5 \mathrm{~mm} \text { thick; winged screws; } \\
\text { screws angle: } 45^{\circ}\end{array}$ & 5.79 & 0.98 & \\
\hline $\begin{array}{l}\text { Plywood with CFS of the } 1.5 \mathrm{~mm} \text { thick; non-winged } \\
\text { screws, screws angle: } 45^{\circ}\end{array}$ & 6.21 & 1.31 & \\
\hline $\begin{array}{l}\text { Plywood with CFS of the } 2.4 \mathrm{~mm} \text { thick, winged screws, } \\
\text { screws angle: } 0^{\circ}\end{array}$ & 5.26 & 0.62 & \\
\hline $\begin{array}{l}\text { Plywood with CFS of the } 2.4 \mathrm{~mm} \text { thick; winged screws, } \\
\text { screws angle: } 45^{\circ}\end{array}$ & 5.60 & 1.20 & \\
\hline $\begin{array}{l}\text { Plywood with CFS of the } 2.4 \mathrm{~mm} \text { thick; non-winged } \\
\text { screws, screws angle: } 45^{\circ}\end{array}$ & 6.15 & 1.40 & \\
\hline
\end{tabular}

$k_{s}$ : slip modulus according to EN 12512 (0.4: initial stiffness)

Hassanieh et al. (2017a) presented the push-out tests on specimens with coach screws, dog screws, and bolts embedded in the grout pocket (BGP); the resulting failure modes in steel-CLT are shown in Fig. 3. The BGP is an STC connection that allows minimizing overhead works while preserving the possibility for prefabrication and deconstruction of STC floors and beams. The experimental results are presented in Table 3. Since the modulus of elasticity and compression strength of the cementitious grout are higher than mechanical properties of spruce wood (CLT), the BGP had higher strength and stiffness compared to screwed connection. The peak load capacity of the BGP was up to 2.4 times higher and the slip modulus was up to 10 times higher compared to coach screws and up to 4 times if compared with dog screws. Despite the similar peak load capacities achieved for both coach and dog screw connections, the slip modulus of dog screws connection was significantly higher (up to 4.4 times), probably due to steel grade considered. 
Table 3. Mean Values of the Mechanical Properties of Connections Systems with Steel Profile and CLT

\begin{tabular}{|c|c|c|c|}
\hline Connection system & $\begin{array}{l}\text { Peak } \\
\text { load } \\
\text { capacity } \\
\text { (kN) }\end{array}$ & $\begin{array}{l}\text { Slip } \\
\text { modulus } \\
(\mathrm{kN} / \mathrm{mm})\end{array}$ & $\begin{array}{l}\text { Reference } \\
\text { composite } \\
\text { solution }\end{array}$ \\
\hline $\begin{array}{l}\text { I-A-1 - L-shape thin profiles welded on both sides of } \\
\text { the steel beam-CLT panel - self-tapping screw - } \\
\text { perpendicular }\end{array}$ & 21.45 & $k_{\mathrm{s} 0.4}=8.2$ & \multirow{3}{*}{$\begin{array}{l}\text { Loss et al. } \\
(2016 a) \\
\text { Steel-CLT }\end{array}$} \\
\hline $\begin{array}{l}\text { I-A-3 - Steel elements welded on both sides of the } \\
\text { steel thick beam-CLT panel - full-threaded self-tapping } \\
\text { inclined screw. }\end{array}$ & 41.06 & $k_{\mathrm{s} 0.4}=31.0$ & \\
\hline $\begin{array}{l}\text { I-B-7 - Steel drilled plate with smooth surface welded } \\
\text { to the steel beam and connected to the CLT panel } \\
\text { using epoxy-based resin; partially drilled plate and } \\
\text { epoxy-based resin with a different aggregate dosage. }\end{array}$ & 195.01 & $k_{\mathrm{s} 0.4}=372.4$ & \\
\hline Screw: $12 \mathrm{~mm}$ without nail plate & 35.78 & $k_{s 0.6}=9.52$ & \multirow{8}{*}{$\begin{array}{l}\text { Hassanieh } \\
\quad \text { et al. } \\
(2016 \mathrm{c}) \\
\text { Steel-CLT }\end{array}$} \\
\hline Screw: $12 \mathrm{~mm}$ with nail plate & 38.88 & $k_{\mathrm{s} 0.6}=16.23$ & \\
\hline Screw: $16 \mathrm{~mm}$ without nail plate & 49.87 & $k_{\mathrm{s} 0.6}=8.21$ & \\
\hline Screw: $16 \mathrm{~mm}$ with nail plate & 63.98 & $k_{\mathrm{s} 0.6}=26.80$ & \\
\hline Screw: $20 \mathrm{~mm}$ without nail plate & 67.52 & $k_{\mathrm{s} 0.6}=6.11$ & \\
\hline Bolt: $12 \mathrm{~mm}$ without nail plate & 79.88 & $k_{\mathrm{s} 0.6}=6.26$ & \\
\hline Bolt:16 mm without nail plate & 123.40 & $k_{\mathrm{s} 0.6}=9.66$ & \\
\hline $\begin{array}{l}\text { Bolts: } 12 \mathrm{~mm} \text {, embedded in the grout pocket ( } 50 \mathrm{~mm} \times \\
50 \mathrm{~mm} \times 5 \mathrm{~mm} \text { ) }\end{array}$ & 131.13 & $k_{\mathrm{s} 0.6}=34.94$ & \\
\hline $\begin{array}{l}\text { Coach screw d: } 12 \mathrm{~mm} ; \mathrm{l}: 100 \mathrm{~mm} \text {; fasteners steel } \\
\text { grade: } 4.6 \text { (loaded perpendicular to the grain) }\end{array}$ & 37.5 & $\begin{array}{l}k_{\mathrm{s} 0.4}=6.29 \\
k_{\mathrm{s} 0.6}=2.14\end{array}$ & \multirow{10}{*}{$\begin{array}{l}\text { Hassanieh } \\
\text { et al. } \\
\text { (2017a) } \\
\text { Steel-CLT }\end{array}$} \\
\hline $\begin{array}{l}\text { Coach screw d: } 16 \mathrm{~mm} \text {; I: } 100 \mathrm{~mm} \text {; fasteners steel } \\
\text { grade: } 4.6 \text { (loaded perpendicular to the grain) }\end{array}$ & 53.6 & $\begin{array}{l}k_{\mathrm{s} 0.4}=6.81 \\
k_{\mathrm{s} 0.6}=6.11\end{array}$ & \\
\hline $\begin{array}{l}\text { Coach screw d: } 20 \mathrm{~mm} \text {; l: } 100 \mathrm{~mm} \text {; fasteners steel } \\
\text { grade: } 4.6 \text { (loaded perpendicular to the grain) }\end{array}$ & 74.9 & $\begin{array}{l}k_{\mathrm{s} 0.4}=6.43 \\
k_{\mathrm{s} 0.6}=6.24\end{array}$ & \\
\hline $\begin{array}{l}\text { Dog screw d: } 16 \mathrm{~mm} \text {; l: } 125 \mathrm{~mm} \text {; fasteners steel grade: } \\
5.8 \text { (loaded parallel to the grain) }\end{array}$ & 54.4 & $\begin{array}{l}k_{\mathrm{s} 0.4}=29.65 \\
k_{\mathrm{s} 0.6}=11.66\end{array}$ & \\
\hline $\begin{array}{l}\text { Dog screw d: } 19 \mathrm{~mm} \text {; l: } 135 \mathrm{~mm} \text {; fasteners steel grade: } \\
5.8 \text { (loaded parallel to the grain) }\end{array}$ & 68.6 & $\begin{array}{l}k_{\mathrm{s} 0.4}=17.16 \\
k_{\mathrm{s} 0.6}=6.23\end{array}$ & \\
\hline $\begin{array}{l}\text { Bolts embedded in the grout pocket }(60 \mathrm{~mm} \times 135 \mathrm{~mm}) \\
\mathrm{d}: 12 \mathrm{~mm} \text {; I: } 130 \mathrm{~mm} \text {; fasteners steel grade: } 8.8 \\
\text { (loaded parallel to the grain) }\end{array}$ & 82.9 & $\begin{array}{l}k_{\mathrm{s} 0.4}=39.53 \\
k_{\mathrm{s} 0.6}=29.76\end{array}$ & \\
\hline $\begin{array}{l}\text { Bolts embedded in the grout pocket }(80 \mathrm{~mm} \times 135 \mathrm{~mm}) \\
\mathrm{d}: 16 \mathrm{~mm} \text {; l: } 130 \mathrm{~mm} \text {; fasteners steel grade: } 4.6 \\
\text { (loaded parallel to the grain) }\end{array}$ & 103.4 & $\begin{array}{l}k_{\mathrm{s} 0.4}=58.68 \\
k_{\mathrm{s} 0.6}=45.26\end{array}$ & \\
\hline $\begin{array}{l}\text { Bolts embedded in the grout pocket }(80 \mathrm{~mm} \times 135 \mathrm{~mm} \text { ) } \\
\mathrm{d}: 16 \mathrm{~mm} \text {; I: } 130 \mathrm{~mm} \text {; fasteners steel grade: } 8.8 \\
\text { (loaded parallel to the grain) }\end{array}$ & 126.9 & $\begin{array}{l}k_{\mathrm{s} 0.4}=55.12 \\
k_{\mathrm{s} 0.6}=45.77\end{array}$ & \\
\hline $\begin{array}{l}\text { Bolts embedded in the grout pocket }(60 \mathrm{~mm} \times 135 \mathrm{~mm}) \\
\mathrm{d} \text { : } 20 \mathrm{~mm} \text {; I: } 130 \mathrm{~mm} \text {; fasteners steel grade: } 8.8 \\
\text { (loaded parallel to the grain) }\end{array}$ & 153.3 & $\begin{array}{l}k_{\mathrm{s} 0.4}=64.57 \\
k_{\mathrm{s} 0.6}=53.68\end{array}$ & \\
\hline $\begin{array}{l}\text { Bolts embedded in the grout pocket }(80 \mathrm{~mm} \times 135 \mathrm{~mm} \text { ) } \\
\mathrm{d}: 20 \mathrm{~mm} \text {; I: } 130 \mathrm{~mm} \text {; fasteners steel grade: } 8.8 \\
\text { (loaded parallel to the grain) }\end{array}$ & 159.7 & $\begin{array}{l}k_{\mathrm{s} 0.4}=77.19 \\
k_{\mathrm{s} 0.6}=63.08\end{array}$ & \\
\hline
\end{tabular}

$k_{s}$ : slip modulus according to EN 12512 (0.4: initial stiffness; 0.6: pre-peak stiffness)

$d$ : nominal diameter of the connector $(\mathrm{mm})$;

l: length of the connector $(\mathrm{mm})$. 
Yang et al. (2020) presented an experimental study on an STC connection system composed of steel H-section and glulam using bolt connectors and SDS (Self-Drilling Screw), which is one type of self-tapping screw but typically has denser steel thread. The static push-out results showed the influence of the type, diameter, and spacing of shear connectors, and thickness of glulam in composite mechanical properties. The connector varied as bolt $(6 \mathrm{~mm}$ and $8 \mathrm{~mm})$ and $5.5 \mathrm{~mm}$ SDS; the specimens only varied in bolt spacing, i.e. $100 \mathrm{~mm}, 150 \mathrm{~mm}$, and $200 \mathrm{~mm}$; and the glulam flange thickness was varied as $30 \mathrm{~mm}, 40 \mathrm{~mm}, 50 \mathrm{~mm}$, and $60 \mathrm{~mm}$, but all other parameters were kept the same. The ultimate load carrying capacity was influenced by the bolt diameter, spacing, and glulam flange thickness. Table 4 shows that the highest ultimate load $\left(F_{\mathrm{u}}=69.28 \mathrm{kN}\right)$ was recorded for glulam flange thickness of $50 \mathrm{~mm}$ and $8 \mathrm{~mm}$ nominal diameter of the connector. The SDS connectors were more ductile and produced stiffer connection when compared to the bolted connectors for all considered STC specimens, which can be confirmed by the higher values of the slip modulus $\left(k_{\mathrm{s} 0.4}=36.51 \mathrm{kN} / \mathrm{mm}\right)$ and $\left(k_{\mathrm{s} 0.6}=27.92 \mathrm{kN} / \mathrm{mm}\right)$. The lowest ultimate load $\left(F_{\mathrm{u}}=36.41 \mathrm{kN}\right)$ and slip modulus $\left(k_{\mathrm{s} 0.4}=10.74 \mathrm{kN} / \mathrm{mm}\right.$ and $k_{\mathrm{s} 0.6}=10.62$ $\mathrm{kN} / \mathrm{mm})$ were obtained for smallest glulam flange thickness $(30 \mathrm{~mm})$ and $6 \mathrm{~mm}$ nominal diameter of the connector. According to the results, the ultimate load of connections was directly proportional to the bolt diameter but was inversely proportional to the bolt spacing.

Table 4. Mean Values of the Mechanical Properties of Connections Systems with Steel and Glulam

\begin{tabular}{|c|c|c|c|c|}
\hline Connection system & $\begin{array}{c}\text { Ultimate } \\
\text { load } \\
\text { (kN) }\end{array}$ & $\begin{array}{c}k_{\mathrm{s} 0.4} \\
(\mathrm{kN} / \mathrm{mm})\end{array}$ & $\begin{array}{c}k_{\mathrm{s} 0.6} \\
(\mathrm{kN} / \mathrm{mm})\end{array}$ & $\begin{array}{c}\text { Reference } \\
\text { composite } \\
\text { solution }\end{array}$ \\
\hline Bolt - t: 50 mm; d: 6 mm; $a_{1}: 100$ mm; l: 340 mm; & 43.13 & 12.47 & 13.43 & \multirow{8}{*}{$\begin{array}{c}\text { Yang et al. } \\
(2020) \\
\text { Steel- } \\
\text { Glulam }\end{array}$} \\
\hline Bolt - t: $50 \mathrm{~mm}$; d: $8 \mathrm{~mm} ; \mathrm{a}_{1}: 100 \mathrm{~mm}$; l: $340 \mathrm{~mm}$; & 69.28 & 17.03 & 17.85 & \\
\hline Bolt - t: $50 \mathrm{~mm}$; d: $6 \mathrm{~mm}$; $\mathrm{a}_{1}: 150 \mathrm{~mm}$; l: $390 \mathrm{~mm}$; & 39.27 & 12.71 & 13.67 & \\
\hline Bolt - t: $50 \mathrm{~mm}$; d: $6 \mathrm{~mm}$; $\mathrm{a}_{1}: 200 \mathrm{~mm}$; l: $440 \mathrm{~mm}$; & 37.63 & 12.85 & 13.23 & \\
\hline Bolt - t: $30 \mathrm{~mm}$; d: $6 \mathrm{~mm} ; \mathrm{a}_{1}: 100 \mathrm{~mm}$; l: $340 \mathrm{~mm}$; & 36.41 & 10.74 & 10.62 & \\
\hline Bolt - t: $40 \mathrm{~mm}$; d: $6 \mathrm{~mm}$; $\mathrm{a}_{1}: 100 \mathrm{~mm}$; l: $340 \mathrm{~mm}$; & 49.04 & 11.49 & 11.50 & \\
\hline Bolt - t: $60 \mathrm{~mm}$; d: $6 \mathrm{~mm}$; $\mathrm{a}_{1}: 100 \mathrm{~mm}$; l: $340 \mathrm{~mm}$; & 37.16 & 12.13 & 12.63 & \\
\hline $\begin{array}{l}\text { Self-drilling screw: } t: 50 \mathrm{~mm} ; d: 5.5 \mathrm{~mm} ; a_{1}: 100 \\
\mathrm{~mm} ; \mathrm{l}: 340 \mathrm{~mm} \text {. }\end{array}$ & 39.55 & 36.51 & 27.92 & \\
\hline
\end{tabular}

$k_{s}$ : slip modulus according to EN 12512 (0.4: initial stiffness; 0.6: pre-peak stiffness);

$t$ : glulam flange thickness (mm);

$d$ : nominal diameter of the connector $(\mathrm{mm})$;

$a_{1}$ : parallel to the grain connector spacing $(\mathrm{mm})$;

l: length of steel section and glulam ( $\mathrm{mm})$.

In general, the proposed connection types were tested to assess the enhancement achieved compared to common type mechanical fasteners for STC structures. The experimental results showed that the connection systems were efficient and could provide higher performance. However, the material behavior can significantly affect the mechanical performance, as can the diameter, spacing, and orientation of the connector. The composite structures with steel profile and CLT had higher values of both slip modulus and ultimate load capacity. In addition, the composite solutions comprised of CFS beams reinforced by timber lamellas or assembled with wood-based panels had lower values of the mechanical properties than structures composed with steel profile and timber (e.g. CLT and LVL). It is expected that the mechanical performance of the connection system CFS- 
CLT composite solutions had higher performance than the solution presented by Vella et al. (2020), which was composed by CFS and wood-based panel. Connection systems proposed by Awaludin et al. (2016), Loss et al. (2016a), Hassanieh et al. (2016c), and Hassanieh et al. (2017a) should be tested in CFS-CLT composite solution in order to analyze the improvement technologies that can achieve in mechanical properties.

\section{DESIGN AND ANALYSIS ANALYTICAL MODELS FOR COMPOSITE STRUCTURES}

Within composite structures, there are standards for the design of steel-concrete composite structures (CEN 2004) and timber-concrete composite bridges (Dias et al. 2021). On the other hand, design and standard recommendations for steel-timber composite structures are not well established (Kyvelou et al. 2017a).

The $\gamma$-method is derived from the approximation of the Möhler (1956) method for composite beams with flexible connection and is proposed in Annex B of Eurocode 5, Part 1-1 (CEN 2004a). This method is considered for all materials comprising that the composite structures remain within the linear-elastic range. Loss and Davison (2017) used the $\gamma$-method to design the STC floor solution with semi-rigid connection, in which the CFS beams, CLT panel, and connections remain within the linear-elastic range and that the ultimate load was more conservative compared to the experimental bearing capacities of the systems. The design equations are presented for the attained degree of shear connection and determination of the effective bending stiffness and the normal stress.

Hassanieh et al. (2016a) proposed an empirical model to characterize the load-slip behavior of steel-LVL composite slabs with screw, bolt connectors, and reinforcing nail plates. The model was inspired by the Ramberg-Osgood model (1943) that has been widely used in the analysis of steel structures. In Hassanieh et al. (2017a), the authors applied this model for the load-slip behavior, stiffness, and strength of steel-CLT connections with dog screw and bolt connectors incorporated in the grout pocket. The proposed shear load versus slip function has seven parameters, which were estimated by non-linear regression. According to the authors, the analytical load-slip curves correlated very well with experimental results $\left(\mathrm{R}^{2}=0.97\right)$ and can be incorporated into component-based finite element models, non-linear analysis, and design of hybrid STC lap joints (Hassanieh et al. 2016a).

Chybiński and Polus (2019) developed a theoretical analysis of the aluminiumtimber composite (ATC) structures, through push-out tests of screwed connection to obtain the slip modulus and the peak load capacity. The theoretical analysis of the ATC beams was evaluated from the method of elastic and plastic resistance to bending. The method from the plastic resistance to bending consisted of determining the position of the plastic axis that considered a tensile force in the aluminium beam section that was equal to the compression force in the timber slab. The analytical estimation from the plastic model was about $7 \%$ lower than the mean bending strength from the tests. However, the theoretical model did not take into account the sudden tensile fracture and the slip that influence in the stiffness and the strength of the composite beam that may be significant.

After several experimental and numerical tests on composite flooring systems with CFS and wood-based floorboard, Kyvelou et al. (2017a) proposed a method for its design, considering the theoretical bases of CFS from Eurocode 3, Part 1-3 (CEN 2006) and steelconcrete composite structures according to the Eurocode 4 (CEN 2004). The bending 
moment capacity of the composite beam was calculated from the attained degree of partial shear connection, which ranged between that of the bare steel beam and the equivalent composite beam with full-composite action. The comparisons with the results of 12 experimental tests and 80 numerical models demonstrated that the proposed design method gives accurate predictions of the bending moment capacity and flexural stiffness.

\section{NUMERICAL MODEL OF STEEL-TIMBER COMPOSITE STRUCTURES}

Kyvelou et al. (2018) developed a numerical model in ABAQUS software to reproduce the behavior of the CFS-wood-based composite system. The model included geometric imperfections, the load-slip response of the shear connection, geometric and material nonlinearities, as well as it was able to accurately capture the local and distortional buckling. Parametric analyses were performed to assess the influence of the depth and thickness of the CFS cross-section, as well as the spacing between the fasteners. The numerical study identified significant benefits in terms of structural response as a result of the composite action behavior. An increase up to $140 \%$ was obtained in bending moment capacity, and there was a $40 \%$ increase in stiffness.

Loss and Davison (2017) developed finite element models of STC floor solutions (Fig. 2) in SAP2000 software, which allowed the characterization of the structural behavior of the floor components with sufficient accuracy. The constitutive laws for wood have been derived from the rules provided in Eurocode 5 (CEN 2004a) and for steel in Eurocode 3 (CEN 2006). The authors used frame elements to reproduce the behavior of the steel beams and connectors, and shell elements to represent the CLT panels. The mechanical characteristics of both the steel and timber elements were calibrated based on the preliminary tests. The multi-layered material was assumed to define the CLT panel with different mechanical properties for each layer, cross-direction, and the grain direction. The link elements were included to account for the interaction of CLT panels and the steel beams, and the plastic hinges were used to account for the nonlinear mechanical behavior of the connections. Non-linear incremental analysis of the simply supported floor components loaded under displacement control was performed. The numerical results were compared with experimental tests, and the absolute error between load-deflection curves was less than $9.5 \%$. Regarding the effective stiffness in serviceability, the FEM value was $10 \%$ lower than the experimental value.

Hassanieh et al. (2016b) developed 1D and 2D nonlinear finite element models of STC beam specimens that were previously used to calibrate the models, namely to achieve the peak load carrying capacity, failure mode, load-slip, load-deflection, and load-support rotation response. The $1 \mathrm{D}$ frame e 2D model were considered continuous based non-linear finite element models of the composite beams, using OpenSees and ABAQUS, respectively. From the numerical results, it was verified that the $1 \mathrm{D}$ and $2 \mathrm{D}$ models were efficient to predict the composite structural behavior compared to the experimental results. Hassanieh et al. (2017b) developed 3D finite element models of steel-timber connections with dowel type fasteners. The appropriate constitutive laws for the consistent materials were adopted. These considered geometrical and material nonlinearities to steel including yield strength and plastic hardening, and the anisotropic behavior and failure modes of the LVL and CLT. The non-linear behavior of the contact interface between the steel and timber components was incorporated in the models. A parametric study was carried out to determine the influence of different parameters and the validation of finite element models. 
The numerical modeling was able to replicate adequately the behavior of the load-slip response and failure mode of the STC connections tested.

Navaratnam et al. (2021) evaluated the FE model of CFS-CLT composite beam for the floor system to apply in sustainable modular buildings. The numerical model was validated with experimental results of the literature. Each member was evaluated, as well as the performance of composite action, with and without connection. The moment capacity enhancement found was about $20 \%$ due to the mobilization of CFS-CLT beam in composite action.

\section{DYNAMIC PERFORMANCE}

Studies were carried out on the vibration behavior of STC structural systems. Natural frequencies were found to be considerably larger than $8 \mathrm{~Hz}$, which is the limit recommended by Eurocode 5 (CEN 2004a; Chiniforush et al. 2017, 2019a). The STC floors have relatively high stiffness, are lighter, and have lower intrinsic damping compared to conventional steel-concrete composite floors. Therefore, the vibration performance is a major serviceability concern that should be checked, as human comfort needs to be ensured (Chiniforush et al. 2019a; Hassanieh et al. 2019). The different connector types of STC beam showed the same vibration frequency range for the first three flexural modes, and the connector type was not a determining factor in the dynamic response of the STC beams (Chiniforush et al. 2017). Hassanieh et al. (2019) studied the serviceability performance of the STC under human-induced excitation through experimental tests and numerical models. The vibration assessments according to standard guidelines have shown that STC floors can be used for residential buildings, offices, sport, and industrial use. The authors also emphasized that the complexity of the vibration behavior increases with the continuity of prefabricated CLT slab across the different span and the composite action between the steel beams and CLT slab.

From another perspective, the STC structures are reliable alternatives in regions of high seismic risk and can meet the building code requirements and be deemed a reliable system under seismic design consideration. In addition, the most significant factor for structural reliability is the ground motion, besides the ductility factor, structural weight, fastener types, and connection stiffness (Tesfamariam et al. 2014; Zhang et al. 2018). According to Asdrubali et al. (2017), the lightness, strength, viscoelastic properties, and deformability make wood suitable in seismic constructions. The lightness of timber structures is a crucial issue because it reduces the induced stresses through seismic forces, as well as affects the sensibility to the seismic action at the operational limit state due to the low modulus of elasticity of timber.

Ataei et al. (2019a) assessed the cyclic load versus slip response of the shear connectors in the steel-CLT composite. The authors demonstrated the high ductility and the energy dissipating capacity of the mechanical shear connectors in STC elements subjected to cyclic loads, considering the effect of type connector, direction, connector size, and orientation of the CLT panels concerning the direction of the load. The results showed the incremental damage and crushing of timber in the front/back, of the shear connectors subjected to the cyclic loads, which caused the strength deterioration in cyclic loading to be higher than that in monotonic tests. According to the authors, previous studies on timber shear walls and timber connections with mechanical shear connectors such as nails showed similar results. 


\section{CONCLUDING REMARKS}

This paper has provided a literature review of the state-of-the-art about the steeltimber composite (STC) solutions that cover the different research topics related, namely: mechanical performance; connection systems; numerical and analytical models, and standard methods for steel and timber structures. Particularly, this paper has introduced an analysis of the composite system comprising cold-formed steel and cross-laminated timber. This is a new area of study and, therefore, has a significant potential to be implemented as a highly industrialized construction and an effective solution for buildings. The main highlights of this review are listed below.

1. There are several advantages of STC structures: enabling highly industrialized construction, high capacity-to-self-weight ratio, structural in-plan stability, and lower environmental impact.

2. Buckling failure is the main drawback associated with the CFS profiles, especially when submitted to stresses such as bending, compression, or their combination. There are some studies regarding the use of CFS profiles stiffened by timber lamellas or joined in timber panels. These composite solutions can minimize the instability of the CFS profiles, and increasing also the efficiency of CLT panels.

3. The connection system is a key factor to obtain the desired composite action of the structures. Different technologies and mechanical performances were presented (i.e. CFS-timber, CFS-wood-based panel, steel-CLT, steel-LVL, steel-glulam). The material properties, components to reinforce and the connection types were clearly the factors that presented higher influence on the composite system behavior. The connection systems used for CFS-CLT should be further investigated. In addition, technologies of connection presented in this paper for steel-CLT can be experimentally tested to analyze their performance on the CFS-CLT composite floor.

4. The existing numerical models were developed for CFS-wood based panel, CFSCLT, and steel-CLT structures. The parameters of the models presented were calibrated to their experimental results, providing good accuracy, around $10 \%$. Simplifications in 1D and 2D models were also analyzed and good approximations with 3D models were obtained.

5. The literature showed that there are still some limitations on the available codes and standards for the design of STC structures; consequently, the approximated and conservative model is adopted to design the STC element of buildings.

6. The researchers reported that the vibration performance of the STC is a major serviceability concern that should be checked due to the relatively high stiffness, lightness, deformability, and lower intrinsic damping. The ductility and energy dissipating capacity of the connection systems are factors that determine the dynamic response of the STC structures. Since the complexity of the vibration behavior, further studies are essential to analyze the behavior of the CFS-CLT composite floors. 


\section{ACKNOWLEDGMENTS}

This work was partly financed by FEDER funds through the Competitiveness Factors Operational Programme - COMPETE, by national funds through FCT Foundation for Science and Technology, within the scope of the Project POCI-01-0145FEDER-007633; and through the Regional Operational Programme for the Centro Region (Centro 2020) within the scope of the Project SUSpENsE - CENTRO-01-0145-FEDER000006 and the Project F4F - Forest for Future - CENTRO-08-5864-FSE-000031.

The authors are also grateful to both the University of Coimbra - UC, Department of Civil Engineering - DEC, Institute for Sustainability and Innovation in Structural Engineering - ISISE, and the Forest Competence and Innovation Center - SerQ for all support provided in the development of this paper.

\section{REFERENCES CITED}

Akotuah, A. O., Ali, S. G., Erochko, J., Zhang, X., and Hadjisophocleous, G. V. (2015). "Study of the fire performance of hybrid steel-timber connections with full-scale tests and finite element modelling," in: Proceedings of the International Conference in Dubrovnik, 15-16 October 2015. Applications of Structural Fire Engineering. Prague 6: Czech Technical Univ Prague. DOI: 10.14311/asfe.2015.039.

Asdrubali, F., Ferracuti, B., Lombardi, L., Guattari, C., Evangelisti, L., and Grazieschi, G. (2017). "A review of structural, thermo-physical, acoustical, and environmental properties of wooden materials for building applications," Building and Environment 114, 307-332. DOI: 10.1016/j.buildenv.2016.12.033.

Ataei, A., Chiniforush, A. A., Bradford, M., and Valipour, H. (2019a). "Cyclic behaviour of bolt and screw shear connectors in steel-timber composite (STC) beams," Journal of Constructional Steel Research 161, 328-340. DOI: 10.1016/j.jcsr.2019.05.048.

Ataei, A., Valipour, H. R., Bradford, M. A., and Chiniforush, A. A. (2019b).

"Experimental study of steel-timber composite beam-to-column joints with extended end plates," Construction and Building Materials 226, 636-650. DOI: 10.1016/j.conbuildmat.2019.07.154.

Awaludin, A., Danastri, A. D., and Supriyadi, B. (2016). "Development of cold formed steel-timber composites for roof structures: Connection systems," International Journal of Technology 7(6), 1117-1127. DOI: 10.14716/ijtech.v7i6.2719.

Awaludin, A., Rachmawati, K., Aryati, M., and Danastri, A. D. (2015). "Development of cold formed steel-timber composite for roof structures: Compression members," Procedia Engineering 125, 850-856. DOI: 10.1016/j.proeng.2015.11.052.

Bjertnæs, M. A., and Malo, K. A. (2014). "Wind-induced motions of 'Treet'-A 14-storey timber residential building in Norway," in: WCTE 2014 - World Conference on Timber Engineering, Quebec. Canada. 10-14 August 2014.

Bradford, M. A., Hassanieh, A., Valipour, H. R., and Foster, S. J. (2017). "Sustainable steel-timber joints for framed structures," Procedia Engineering 172, 2-12. DOI: 10.1016/j.proeng.2017.02.011.

Ceccotti, A. (2002). "Composite concrete-timber structures," Progress in Structural Engineering and Materials 4(3), 264-275. DOI: 10.1002/pse.126.

CEN. (2006). "Eurocode 3: Design of steel structures - Part 1-1: General rules and rules for buildings,” European Committee for Standardization, Brussels, Belgium. 
CEN. (2006). "Eurocode 3: Design of steel structures - Part 1-3: General rules Supplementary rules for cold-formed members and sheeting," European Committee for Standardization, Brussels, Belgium.

CEN. (2004). "Eurocode 4. Design of composite steel and concrete structures - Part 1-1: General rules and rules for buildings," European Committee for Standardization, Brussels, Belgium.

CEN. (2004a). "Eurocode 5: Design of timber structures - Part 1-1: General rules and rules for buildings," European Committee for Standardization, Brussels, Belgium.

Chiniforush, A. A., Akbar Nezhad, A., Valipour, H., and Dackermann, U. (2017). "Dynamic response of steel-timber composite (STC) beams," in: $24^{\text {th }}$ International Congress on Sound and Vibration (ICSV24). 23-27 July 2017. London.

Chiniforush, A. A., Akbarnezhad, A., Valipour, H., and Xiao, J. Z. (2018). "Energy implications of using steel-timber composite (STC) elements in buildings," Energy and Buildings 176(203-215). DOI: 10.1016/j.enbuild.2018.07.038.

Chiniforush, A. A., Makki Alamdari, M., Dackermann, U., Valipour, H. R., and Akbarnezhad, A. (2019a). "Vibration behaviour of steel-timber composite floors, part (1): Experimental \& numerical investigation," Journal of Constructional Steel Research 161, 244-257. DOI: 10.1016/j.jcsr.2019.07.007.

Chiniforush, A. A., Valipour, H., Bradford, M., and Akbarnezhad, A. (2019b). "Longterm behaviour of steel-timber composite (STC) shear connections," Engineering Structures 196, 109356. DOI: 10.1016/j.engstruct.2019.109356.

Chybiński, M., and Polus, Ł. (2019). "Theoretical, experimental and numerical study of aluminium-timber composite beams with screwed connections," Construction and Building Materials 226, 317-330. DOI: 10.1016/j.conbuildmat.2019.07.101.

Dias, A. (2012). "Analysis of the nonlinear behavior of timber-concrete connections," Journal of Structural Engineering 138(9), 1128-1137. DOI: 10.1061/(Asce)St.1943$541 x .0000523$

Dias, A., Fragiacomo, M., Harris, R., Kuklík, P., Rajčić, V., and Schänzlin, J. (2021). "Technical specification - Eurocode 5: Design of timber structures-Structural design of timber-concrete composite structures-Common rules and rules for buildings," $3^{\text {rd }}$ Draft. European Committee for Standardization, Brussels.

Hassanieh, A. (2017). "Development of steel-timber composite system for large scale construction," MSc. Sharif University of Technology, Univ. of New South Wales.

Hassanieh, A., Chiniforush, A. A., Valipour, H. R., and Bradford, M. A. (2019). "Vibration behaviour of steel-timber composite floors, Part (2): Evaluation of humaninduced vibrations," Journal of Constructional Steel Research 158, 156-170. DOI: 10.1016/j.jcsr.2019.03.026.

Hassanieh, A., Valipour, H. R., and Bradford, M. A. (2016a). "Experimental and analytical behaviour of steel-timber composite connections," Construction and Building Materials 118, 63-75. DOI: 10.1016/j.conbuildmat.2016.05.052.

Hassanieh, A., Valipour, H. R., and Bradford, M. A. (2016b). "Experimental and numerical study of steel-timber composite (STC) beams," Journal of Constructional Steel Research 122, 367-378. DOI: 10.1016/j.jcsr.2016.04.005.

Hassanieh, A., Valipour, H. R., and Bradford, M. A. (2016c). "Load-slip behaviour of steel-cross laminated timber (CLT) composite connections," Journal of Constructional Steel Research 122, 110-121. DOI: 10.1016/j.jcsr.2016.03.008. 
Hassanieh, A., Valipour, H. R., and Bradford, M. A. (2017a). "Composite connections between CLT slab and steel beam: Experiments and empirical models," Journal of Constructional Steel Research 138, 823-836. DOI: 10.1016/j.jcsr.2017.09.002.

Hassanieh, A., Valipour, H. R., Bradford, M. A., and Sandhaas, C. (2017b). "Modelling of steel-timber composite connections: Validation of finite element model and parametric study," Eng. Structures 138, 35-49. DOI: 10.1016/j.engstruct.2017.02.016.

Hassanieh, A., Valipour, H. R. \& Bradford, M. A. (2017c). "Experimental and numerical investigation of short-term behaviour of CLT-steel composite beams," Engineering Structures, 144(43-57). DOI: 10.1016/j.engstruct.2017.04.052.

Irawati, I. S., Awaludin, A., and Sebastian, N. P. (2017). "The performance of coldformed steel long-span roof structure combined with laminated timber: Cold-formed steel-laminated timber composite," Procedia Engineering 171, 1242-1249. DOI: 10.1016/j.proeng.2017.01.417.

Izumi, B., Tani, A., Toba, N., Nakashima, K., Koshihara, M., Yamanashi, T., Kohno, M., and Winter, W. (2016). "Fire performances of timber-cold formed thin steel plate composite beam," in: WCTE 2016 - World Conference on Timber Engineering, Vienna. Austria. 22-25 August 2016.

Keipour, N., Valipour, H. R., and Bradford, M. A. (2018a). "Experimental study of steeltimber composite (STC) beam to steel column joints having a flush end-plate," Engineering Structures 174, 906-918. DOI: 10.1016/j.engstruct.2018.08.009.

Keipour, N., Valipour, H. R., and Bradford, M. A. (2018b). "Steel-timber composite beam-to-column joints: Effect of connections between timber slabs," Journal of Constructional Steel Research 151, 132-145. DOI: 10.1016/j.jcsr.2018.09.019.

Kuhlmann, U., and Schänzlin, J. (2008). "A timber-concrete composite slab system for use in tall buildings," Structural Engineering International 18, 174-178. DOI: $10.2749 / 101686608784218707$.

Kyvelou, P., Gardner, L., and Nethercot, D. A. (2015). "Composite action between coldformed steel beams and wood-based floorboards," International Journal of Structural Stability and Dynamics 15(8), 1540029. DOI: 10.1142/S0219455415400295.

Kyvelou, P., Gardner, L., and Nethercot, D. A. (2017a). "Design of composite coldformed steel flooring systems," Structures 12, 242-252. DOI: 10.1016/j.istruc.2017.09.006.

Kyvelou, P., Gardner, L., and Nethercot, D. A. (2017b). "Testing and analysis of composite cold-formed steel and wood-based flooring systems," Journal of Structural Engineering 143(11), 04017146. DOI: 10.1061/(ASCE)ST.1943-541X.0001885.

Kyvelou, P., Gardner, L., and Nethercot, D. A. (2018). "Finite element modelling of composite cold-formed steel flooring systems," Engineering Structures 158, 28-42. DOI: 10.1016/j.engstruct.2017.12.024.

Lawson, R. M., Pedreschi, R., Ogden, R. G., and Grubb, P. J. (2006). "Developments in light steel composites in floors and roofs," Structural Engineer. 84(21), 44-50.

Lawson, R. M., Ogden, R. G., Pedreschi, R., Popo-Ola, S. O. (2008). "Developments of cold-formed steel sections in composite applications for residential buildings," Advances in Structural Engineering 11(6), 651-660.

DOI:10.1260/136943308787543603.

Loss, C., and Davison, B. (2017). "Innovative composite steel-timber floors with prefabricated modular components," Engineering Structures 132, 695-713. DOI: 10.1016/j.engstruct.2016.11.062. 
Loss, C. and Frangi, A. (2017). "Experimental investigation on in-plane stiffness and strength of innovative steel-timber hybrid floor diaphragms," Engineering Structures, 138, 229-244.

Loss, C., Piazza, M., and Zandonini, R. (2014). "Experimental tests of cross-laminated timber floors to be used in timber-steel hybrid structures," in: WCTE 2014 - World Conference on Timber Engineering, Quebec. Canada. 10-14 August 2014.

Loss, C., Piazza, M., and Zandonini, R. (2016a). "Connections for steel-timber hybrid prefabricated buildings. Part I: Experimental tests," Construction and Building Materials 122, 781-795. DOI: 10.1016/j.conbuildmat.2015.12.002.

Loss, C., Piazza, M., and Zandonini, R. (2016b). "Connections for steel-timber hybrid prefabricated buildings. Part II: Innovative modular structures," Construction and Building Materials 122, 796-808. DOI: 10.1016/j.conbuildmat.2015.12.001.

Möhler, K. (1956). "On the load carrying behavior of beams and columns of compound sections with flexible connections," Tech. Univ. Karlsruhe, Germany: Habilitation.

Navaratnam, S., Widdowfield Small, D., Gatheeshgar, P., Poologanathan, K., Thamboo, J., Higgins, C., and Mendis, P. (2021). "Development of cross laminated timber-coldformed steel composite beam for floor system to sustainable modular building construction," Structures 32(681-690). DOI: 10.1016/j.istruc.2021.03.051.

Nouri, F., Bradford, M., and Valipour, H. (2019). "Steel-timber composite beam-tocolumn connections with shear tab," Journal of Structural Engineering 145(3), 04018268. DOI: 10.1061/(ASCE)ST.1943-541X.0002274.

Nouri, F., and Valipour, H. R. (2019). "Semi-rigid partial-strength steel-timber composite (STC) connections with mechanically anchored steel rods," Journal of Constructional Steel Research 158, 560-575.

Ramberg, W., and Osgood, W. R. (1943). "Description of stress-strain curves by three parameters," Technical Note $\mathrm{N}^{\mathrm{o}}$ 902, National Advisory Committee for Aeronautics.

Rhomberg, H., and Bonomo, J. (2011). "LifeCycle tower. High-rise buildings in hybrid timber construction," Proceedings SB11 Helsinki: World Sustainable Building Conference, 2011 Helsinki (Finland). Finnish Association of Civil engineers RIL and VTT Technical Research Centre of Finland.

Sani, M., Muftah, F., and Osman, A. R. (2019). "A review and development of coldformed steel channel columns with oriented strand board sections," Materials TodayProceedings 17(1078-1085). DOI: 10.1016/j.matpr.2019.06.519.

Tesfamariam, S., Stiemer, S. F., Dickof, C., and Bezabeh, M. A. (2014). "Seismic vulnerability assessment of hybrid steel-timber structure: Steel moment-resisting frames with CLT infill," Journal of Earthquake Engineering 18(6), 929-944. DOI: 10.1080/13632469.2014.916240.

Vella, N., Gardner, L., and Buhagiar, S. (2020). "Experimental analysis of cold-formed steel-to-timber connections with inclined screws," Structures 24, 890-904. DOI: 10.1016/j.istruc.2020.02.009.

Wacker, J. P., Dias, A., and Hosteng, T. K. (2020). "100-year performance of timberconcrete composite bridges in the United States," Journal of Bridge Engineering 25(3), 04020006. DOI: 10.1061/(ASCE)BE.1943-5592.0001513.

$\mathrm{Xu}, \mathrm{B} .-\mathrm{H} .$, Bouchair, A., and Racher, P. (2014). "Mechanical behavior and modeling of dowelled steel-to-timber moment-resisting connections," Journal of Structural Engineering 141, 04014165. 
Xu, L., and Tangorra, F. M. (2007). "Experimental investigation of lightweight residential floors supported by cold-formed steel C-shape joists," Journal of Constructional Steel Research 63(3), 422-435. DOI: 10.1016/j.jcsr.2006.05.010.

Yang, R., Li, H., Lorenzo, R., Ashraf, M., Sun, Y., and Yuan, Q. (2020). "Mechanical behaviour of steel timber composite shear connections," Construction and Building Materials 258, 119605. DOI: 10.1016/j.conbuildmat.2020.119605.

Zhang, X. Y., Shahnewaz, M., and Tannert, T. (2018). "Seismic reliability analysis of a timber steel hybrid system," Engineering Structures 167, 629-638. DOI: 10.1016/j.engstruct.2018.04.051.

Article submitted: December 30, 2020; Peer review completed: March 25, 2021; Revised version received and accepted: June 1, 2021; Published: September 10, 2021.

DOI: 10.15376/biores.16.4.Moritani 